\title{
Factors Affecting Visitor Interest to Visit Bhakti Alam as Ecotourism Destination in Pasuruan, East Java
}

\author{
Alfian $^{1}$, Roedy Soelistyono ${ }^{2}$, Iwan Nugroho ${ }^{3}$ \\ ${ }^{1}$ Master Program of Environmental Sciences, University of Brawijaya, Malang, Indonesia \\ ${ }^{2}$ Department of Agrotechnology, Faculty of Agriculture, University of Brawijaya, Malang, Indonesia \\ ${ }^{3}$ Department of Agribusiness, Widyagama Malang University, Malang, Indonesia
}

\begin{abstract}
The aim of the study was to identify factors affecting the decision making of the tourists' interest to visit Bhakti Alam. This study was conducted in Bhakti Alam as one of the ecotourism destination in Tutur, Pasuruan. A set of questionnaire was set up and distributes to 100 visitors in Bhakti Alam on August 2016. In this research, to generate information regarding visitor perception, a series of interview was done. Data was analyzed using multiple linear regression analysis. The research result shows that variables of advertising, public relations, personal marketing, and sale promotion have significant impact on the visiting decision to Bhakti Alam. This condition also supported by determination coefficient value as 0.608 . It means that $60.84 \%$ variables about visiting decision can be explained by decision-making factors, while the rest of $39.16 \%$ explained by another variable that is not being tested. Variables analysed with $\mathrm{T}$ test to advertising, public relations, personal marketing, and sale promotion each partially have a significant impact to visiting decision. The multiple linear result analysis showed that between those free variables and visiting decision has a strong connection. The resulting distribution of respondents answer by Likert analysis showed that variable which has the biggest impact started from sale promotion followed by public relations, personal selling, and advertising. While visiting decision more determined by representative location factor, followed by representative condition, access road, price and products. Therefore it means that environment aspect must be maintained and improved.
\end{abstract}

Keywords: Advertising, Bhakti Alam Pasuruan, Ecotourism, Personal Marketing, Public Relations, Sale Promotion.

\section{INTRODUCTION}

Tourism is one of the huge business, in which it is contributes to the national earning and local economic development. Tourism development provides opportunities to support local development growth. Tourism related to the business activity, and many tourism sites provides interest in the issues of competition [1]. Thus, to run the business well and become competitive, a company has to be able to create and maintain their customers. Regarding to the customers, promotion triggers the consumers to use the product [2].

Bhakti Alam is a ecotourism destination with the main is plantation with diverse tropical fruit. Adinsitrativey, it is located in Ngembal Village, Tutur district, Pasuruhan. Geographically, it is located in 450 to $550 \mathrm{~m}$ above the sea level. The main attraction of Bhakti Alam is various tropical fruits and flowers. The facilities available in the Bhakti Alam are a garden of tropical plants, e.g. durian (Durio zibethinus), melon (Cucumis melo),

\footnotetext{
*orrespondence address:

Alfian

Email : alfian_sahibe@yahoo.com

Address : Graduate School University of Brawijaya, Mayjen Haryono 169, Malang65145
}

starfruit (Averrhoa carambola), dragon fruit (Hylocereus undatus), watermelon (Citrullus lanatus), rambutan (Nephelium lappaceum), jackfruit (Artocarpus integer), jew plum/ kedondong (Spondias Dulcis), litchi (Dimocarpus longan), avocado (Persea americana), and sapodilla (Manilkara zapota). Bhakti Alam also provides tourism package to visit dairy farm. Visitors will be invited directly to the processing of cow's milk from the milking process until processing into pasteurized milk that is ready to drink.

The visitors of Bhakti Alam in 2012 is less than $10 \%$ each month, even it rarely exceeds $5 \%$. In August, there is a significant increase due to the fact that there is Eid Fitr holiday. The highest number of visitors are on Saturday and Sunday, meanwhile on weekday the number of visitors is less because the brochure promotes the two-day package at the weekend [3].

There are some factors which cause less visitors in the particular days [3]. Bhakti Alam is a relative new developed place, thus not many people know precisely its location as well as its offered potential. Every fruit tree in the area has different harvest time. This makes the number of visitors outnumber the riped fruits, and vice 
versa. Second, the brochure is one of the media to promote Bhakti Alam. The brochure is placed in the ecotourism area, consequently the target audience who have not visited the place have no idea about the information in the brochure. Last, the target number of visitor does not meet the facilities in the ecotourism place, making the quality of maintenance is lower and not maximized. Therefore, this study aims to identify the factors affecting the decision making of the tourists' interest to visit Bhakti Alam ecotourism.

\section{RESEARCH METHOD \\ Data Collection}

This study takes place in Bhakti Alam in Pasuruan regency. The type of data collected in this study is primary and secondary data [4]. To collect data in this study using the instrument:

1. The questionnaire; a set of questions prepared to ask to the respondents. This questionnaire is intended to obtain written information from respondents regarding the interests of visited by tourists. Questionnaire data is collected directly, this is done to get the data that is truly objective. Questionnaire data is closed, the question made such that the respondents' answers limited to one alternative answer provided.

2. Interview; gathering information by asking directly the related parties to facilitate data collection both primary and secondary. This is done to get information that cannot be extracted with a questionnaire.

3. The study documents; collect information by studying the written data sources is done to obtain secondary data related to the research conducted, for example, the geographical locations and facilities.

\section{Data Analysis}

Multiple linear regression analysis used to analyze the influence of independent variable (advertising, public relations, personal marketing and sale promotion) dependent on variables the decision on visits. Formula of multiple linear regressions [5] that used in this research was:

$$
Y=a+b_{1} X_{1}+b_{2} X_{2}+b_{3} X_{3}+b_{4} X_{4}+e
$$

Description :

$\mathrm{Y}=$ the purchase decision

$\mathrm{a}=$ Constant

$b_{1}=$ regression coefficient between advertising with the decision visits

$b_{2}=$ regression coefficient between public relations with the decision visits $b_{3}=$ regression coefficient between personal marketing with the decision visits

$b_{4}=$ regression coefficient between sale promotion with the decision visits

$\mathrm{X}_{1}=$ Variable Advertising

$\mathrm{X}_{2}=$ Variable Public Relations

$X_{3}=$ Variable Personal Marketing

$\mathrm{X}_{4}=$ Variable Sale Promotion

$\mathrm{e}=$ error disturbance

Test $T$ was used to assess each free variable whether forming regression model has significant influence with $Y$. Free variable forming regression model inferred significant if the score of $T$ arithmetic $>\mathrm{T}$ table or $-\mathrm{T}$ arithmetic $<-\mathrm{T}$ table or significant score $(p$-value $)<0,05$. The criteria for testing in saw the probabilities value [6].

In the attempt to answer the research question, this study used attitude analysis of Likert scale which is based on the data clasification of attitude scale, score, and category. In this study, the highest and lowest scores are determined. The highest score is 5 and the lowest one is 1 . The answer in between the two scale is adjusted by the existing answer: strongly agree is 5 , agree is 4 , neutral is 3 , disagree is 2 , and strongly disagree is 1 . To get the rank, five questions are asked. Then, the score of each respondent is summed up and the rank the score as follows [7]. Based on the formula, the score is displayed in Table 1.

$$
\begin{aligned}
& \text { category difference }=\frac{\text { the highest score }- \text { the owest score }}{\text { number of category }} \\
& \text { category difference }=\frac{5-1}{5} \\
& \text { category difference }=0,8
\end{aligned}
$$

Table 1. Attitude Scale

\begin{tabular}{llcc}
\hline \multirow{2}{*}{ No } & \multicolumn{3}{c}{ Attitude Scale } \\
\cline { 2 - 4 } & \multicolumn{1}{c}{ Attitude } & Score & Category \\
\hline 1 & Strongly Agree & 5 & $>4.21-5.00$ \\
2 & Agree & 4 & $>3.41-4.20$ \\
3 & Neutral & 3 & $>2.61-3.40$ \\
4 & Disagree & 2 & $>1.81-2.60$ \\
5 & Express disagreement & 1 & $1.00-1.80$ \\
\hline
\end{tabular}

\section{RESULT AND DISCUSSION}

Data processing with multiple linear regression analysis was carried out in several steps to find the effect of independent variable on the dependent variable. We obtained the following summary from the data processing (Table 2). 
Table 2. Result of Multiple Linear Regression Analysis

\begin{tabular}{|c|c|c|c|c|c|}
\hline $\begin{array}{c}\text { Variable } \\
\text { Dependent }\end{array}$ & Variable Independent & $\begin{array}{l}\text { Regression } \\
\text { coefficient }\end{array}$ & T Arithmetic & p-value & Description \\
\hline \multirow{5}{*}{ Decision Visit $(Y)$} & Constant & -2.427 & & & \\
\hline & advertising $\left(\mathrm{X}_{1}\right)$ & 0.332 & 3.362 & 0.001 & Significant \\
\hline & public relations $\left(\mathrm{X}_{2}\right)$ & 0.688 & 3.906 & 0.000 & Significant \\
\hline & personal marketing $\left(X_{3}\right)$ & 0.484 & 3.713 & 0.000 & Significant \\
\hline & sale promotion $\left(\mathrm{X}_{4}\right)$ & 0.754 & 4.385 & 0.000 & Significant \\
\hline \multicolumn{6}{|c|}{$R=0.78$} \\
\hline \multicolumn{6}{|c|}{ Coefficients Determination $\left(R^{2}\right)=0.608(60.8 \%)$} \\
\hline \multicolumn{6}{|c|}{ F-Arithmetic $=36.902$} \\
\hline \multicolumn{6}{|c|}{ F-Table $=2.467$} \\
\hline T-Table = 1.985 & & & & & \\
\hline
\end{tabular}

Results of regression model Table 2 was obtained following equation.

\section{$Y=-2.427+0,332 X_{1}+0.688 X_{2}+0.484 X_{3}+0.754 X_{4}$}

The equation interpreted as follow:

a. a Constant value of -2.427 means that if all variables are zero, then the variable $Y$ will have value of -2.427 .

b. Advertising regression coefficient $\left(X_{1}\right)$ of 0.332 means that if Advertising $\left(X_{1}\right)$ increased by 1 unit, then the variable $Y$ will increase by 0.332 units.

c. Public relations regression coefficient $\left(X_{2}\right)$ of 0.688 means that if Public Relations $\left(X_{2}\right)$ increased by 1 unit, then the variable $Y$ will increase by 0.688 units.

d. Personal marketing regression coefficient $\left(X_{3}\right)$ of 0.484 means that if the Personal marketing $\left(X_{3}\right)$ increased by 1 unit, then the variable $Y$ will increase by 0.484 units.

e. Sale promotion regression coefficient $\left(X_{4}\right)$ of 0.754 means that if the Sales Promotion $\left(X_{4}\right)$ increased by 1 unit, then the variable $Y$ will increase by 0.754 units.

Independent variable forming regression model was concluded to have significant effect if the score of $\mathrm{T}$ arithmetic $>\mathrm{T}$ table or $\mathrm{T}$ arithmetic $<T$ table or the significant value ( $p$-value) $<0.05$. Test for these variables in partial are as follows.

\section{F Test (Simultaneously Testing)}

$F$ test is performed to show whether all of the variables used in the regression model had a significant impact on $Y$ or to measure the accuracy of the models used in the regression test. The hypothesis used in the test are as follows.

$\mathrm{H}_{0}$ : Advertising $\left(X_{1}\right)$, Public relations $\left(X_{2}\right)$, Personal Marketing $\left(X_{3}\right)$ and Sales Promotion $\left(X_{4}\right)$ are jointly does not have significant influence to the visiting decision $(Y) . H_{1}$ : Advertising $\left(X_{1}\right)$, Public relations $\left(X_{2}\right)$, Personal Marketing $\left(X_{3}\right)$ and Sales Promotion $\left(X_{4}\right)$ are jointly have significant effect on visiting decision $(\mathrm{Y})$.

After processing the data the test results obtained the value of $F$ arithmetic 36.902 and the value of $F$ table is 2.467 . It can be seen that the value of $\mathrm{F}$ arithmetic larger than $\mathrm{F}$ table (36.902 > 2.467). It can be concluded that the Advertising $\left(X_{1}\right)$, Public Relations $\left(X_{2}\right)$, the Personal Marketing $\left(X_{3}\right)$ and Sales Promotion $\left(X_{4}\right)$ are jointly have significant effect on the decision to visit $(\mathrm{Y})$.

From the analysis of the research that has been done is known that the influence of advertising, public relations, personal marketing and sales promotion effect are jointly have significant impact to the decision visit to Bhakti Alam. Therefore the model used in this study is feasible and proper to use in subsequent analysis. this condition means that the frequency of visiting decision of travelers to Bhakti Alam is determined by how well the advertising, public relations, personal marketing and sales promotion towards tourists. The influence of these variables can be seen from the value of multiple regression coefficient $(R)$ is $60.8 \%$, which indicates that the correlation or relationship between independent variables together towards the decision Bhakti Alam Agrotourism has been important connections.

\section{Coefficient of Determination}

The coefficient of determination used to see the influence percentage of given variable, i.e. Advertising $\left(X_{1}\right)$, Public Relations $\left(X_{2}\right)$, Personal Marketing $\left(X_{3}\right)$ and Sales Promotion $\left(X_{4}\right)$, which affect the decision to visit $(Y)$. After the value of $R$ 0.780 , the coefficient of determination can be calculated using the following formula: 
KD

$$
\begin{aligned}
& =R^{2} \times 100 \% \\
& =(0.780)^{2} \times 100 \% \\
& =60.84 \%
\end{aligned}
$$

The value obtained from KD 60.84\% which indicates that the Advertising $\left(X_{1}\right)$, Public Relations $\left(X_{2}\right)$, Personal Marketing $\left(X_{3}\right)$ and Sales Promotion $\left(X_{4}\right)$, providing simultaneous effects together amounted to $60.84 \%$ the decision visit (Y). While the remaining $39.16 \%$ influenced by other factors not observed.

\section{Test T (Partial Test)}

\section{Advertising}

Based on Table 2, it is obtained score of $T$ arithmetic on the advertising variable $\left(X_{1}\right)$ of 3.362 (significance of $p$-value 0.001 ). While the value $t$ table with 95 degrees of freedom (n-k-1)

\begin{tabular}{|c|c|c|c|}
\hline No. & Description & Frequency (\%) & Score \\
\hline \multirow[t]{7}{*}{$\mathrm{X}_{1.1}$} & Print Ads & & \\
\hline & Strongly Agree & 12 & 60 \\
\hline & Agree & 54 & 216 \\
\hline & Neutral & 29 & 87 \\
\hline & Disagree & 5 & 10 \\
\hline & Strongly Disagree & 0 & 0 \\
\hline & Total & 100 & 373 \\
\hline \multirow[t]{7}{*}{$X_{1.2}$} & Electronic Ads & & \\
\hline & Strongly Agree & 11 & 55 \\
\hline & Agree & 49 & 196 \\
\hline & Neutral & 33 & 99 \\
\hline & Disagree & 7 & 14 \\
\hline & Strongly Disagree & 0 & 0 \\
\hline & Total & 100 & 364 \\
\hline \multirow[t]{7}{*}{$\mathbf{X}_{1.3}$} & Billboard & & \\
\hline & Strongly Agree & 8 & 40 \\
\hline & Agree & 65 & 260 \\
\hline & Neutral & 24 & 72 \\
\hline & Disagree & 3 & 6 \\
\hline & Strongly Disagree & 0 & 0 \\
\hline & Total & 100 & 378 \\
\hline \multirow[t]{8}{*}{$\mathbf{X}_{1.4}$} & Facilities & & \\
\hline & Strongly Agree & 14 & 70 \\
\hline & Agree & 64 & 256 \\
\hline & Neutral & 20 & 60 \\
\hline & Disagree & 2 & 4 \\
\hline & Strongly Disagree & 0 & 0 \\
\hline & Total & 100 & 390 \\
\hline & Average score & 100 & 3.76 \\
\hline
\end{tabular}
$=1.985$. When compared to the $T$ arithmetic $>T$ table $(3.362>1.985)$.

Sources: Research Result

These tests showed that the Advertising variable $\left(X_{1}\right)$ significantly affects the decision making to visit Bhakti Alam (Y). It is also consistent with the previous study [8] which stated the interest to visit ecotourism objects is based on advertisement, either simultaneously or partially, have a real impact on tourist arrivals. This is consistent with the theory, advertising is a form of communication that does not immediately provide information about the advantages and benefits of the products are structured so that will change someone's mind to make a visit [9].

In terms of advertising variable on the decision visits in Bhakti Alam is based on the calculation of the total questions asked about 4 (four) elements that represent aspects of the decision visits (Table 3). Cumulative table of advertising variable in Bhakti Alam showed a total score of 3.76. This proves that advertising can be influence respondents to visit based on the analysis of attitude scale: agree.

\section{Public relations}

Based on Table 2, it is obtained value of Tarithmetic in the public relations variable $\left(X_{2}\right)$ of 3.906 (significance of $p$-value 0.000 ), while the value of $t$ table with 95 degrees of freedom (n-k1) $=1.985$. When compared the $T$ arithmetic $>T$ table (3.906> 1.985), these tests showed that the Public Relations variable $\left(\mathrm{X}_{2}\right)$ significantly affects the decision making to visit Bhakti Alam (Y). In the study that has been conducted, it is concluded that public relations variables significantly affect tourists' decision making to visit [10]. These results are in accordance with the opinion which reveals that the public relations activities include a variety of programs designed to promote and protect the image of

\begin{tabular}{|c|c|c|c|}
\hline No. & Description & Frequency (\%) & Score \\
\hline \multirow[t]{7}{*}{$X_{2.1}$} & Training Ground & & \\
\hline & Strongly Agree & 18 & 90 \\
\hline & Agree & 51 & 204 \\
\hline & Neutral & 31 & 93 \\
\hline & Disagree & 0 & 0 \\
\hline & Strongly Disagree & 0 & 0 \\
\hline & Total & 100 & 387 \\
\hline \multirow[t]{8}{*}{$X_{2.2}$} & Competition Ground & & \\
\hline & Strongly Agree & 11 & 55 \\
\hline & Agree & 57 & 228 \\
\hline & Neutral & 31 & 93 \\
\hline & Disagree & 1 & 2 \\
\hline & Strongly Disagree & 0 & 0 \\
\hline & Total & 100 & 378 \\
\hline & Average score & 100 & 3.82 \\
\hline
\end{tabular}
the company or individual products [11].

Table 4. Public RelationsVariable $\left(X_{2}\right)$

Sources: Research Result

According to Table 4, it could be seen that in terms of public relations variable on the decision 
visits in Bhakti Alam is based on the calculation of the total question asked about 2 (two) elements that represent aspects of decision visits. Cumulative table of public relations variable in Bhakti Alam showed a total score of 3.82. This proves that public relations can influence respondents to visit based on the analysis of attitude scale: agree.

\section{Personal Marketing}

In Table 2, it is obtained value of T-arithmetic in the personal marketing variable $\left(X_{3}\right)$ of 3.713 (significance of $p$-value 0.000$)$, while the value $t$ table with 95 degrees of freedom $(n-k-1)=1.985$. When compared to the $\mathrm{T}$ arithmetic $>\mathrm{T}$ table (3.713> 1.985), these tests showed that the personal marketing variable $\left(X_{3}\right)$ significantly affects the decision making to visit Bhakti Alam $(\mathrm{Y})$. This study also consistent with the statement that interest to visit ecotourism is based on advertisement, either simultaneously or partially, has a real impact on tourist arrivals [12].

Personal marketing variable on the decision visits in Bhakti Alam ecotourism is based on the calculation of the total question asked on the 3 (three) elements that represent aspects of decision visits (Table 5). Based on cumulative table of personal marketing variable in Bhakti Alam ecotourism with a total score of 4.03 , personal marketing can influence respondents to visit based on the analysis of attitude scale: agree.

Table 5. Personal Marketing Variable $\left(\mathrm{X}_{3}\right)$

\begin{tabular}{|c|c|c|c|}
\hline No. & Description & Frequency (\%) & Score \\
\hline \multirow[t]{7}{*}{$X_{3.1}$} & Presentatition & & \\
\hline & Strongly Agree & 21 & 105 \\
\hline & Agree & 59 & 236 \\
\hline & Neutral & 18 & 54 \\
\hline & Disagree & 2 & 4 \\
\hline & Strongly Disagree & 0 & 0 \\
\hline & Total & 100 & 399 \\
\hline \multirow[t]{7}{*}{$X_{3.2}$} & Confirmation & & \\
\hline & Strongly Agree & 19 & 95 \\
\hline & Agree & 61 & 244 \\
\hline & Neutral & 18 & 54 \\
\hline & Disagree & 2 & 4 \\
\hline & Strongly Disagree & 0 & 0 \\
\hline & Total & 100 & 397 \\
\hline \multirow[t]{8}{*}{$X_{3.3}$} & Reminder & & \\
\hline & Strongly Agree & 32 & 160 \\
\hline & Agree & 52 & 208 \\
\hline & Neutral & 14 & 42 \\
\hline & Disagree & 2 & 4 \\
\hline & Strongly Disagree & 0 & 0 \\
\hline & Total & 100 & 414 \\
\hline & Average score & 100 & 4.03 \\
\hline
\end{tabular}

Sources: Research Result

\section{Sale Promotion}

Based on Table 2, it is obtained value of Tarithmetic in the Sale Promotion variable $\left(\mathrm{X}_{4}\right)$ of 4.385 (significance of $p$-value 0.000 ), while the value $T$ table with 95 degrees of freedom $(n-k-1)$ $=1.985$. When compared to the $\mathrm{T}$ arithmetic $>\mathrm{T}$ table (4.385> 1.985), the tests showed that the Sale Promotion variable $\left(\mathrm{X}_{4}\right)$ significantly affects the decision making to visit Bhakti Alam (Y).

Based on coefficient values in Table 2 , it is known that the independent variables that have the highest coefficient is sales promotion $\left(\mathrm{X}_{4}\right)$ of 0.754 . This means that the sales promotion is the dominant variable in influencing the decision of tourists to visit in Bhakti Alam ecotourism. As previous study mentioned [13], it is concluded that sale promotion variables significantly affect tourists' decision making to visit Bhakti Alam.

Table 6. Sale Promotion Variable $\left(X_{4}\right)$

\begin{tabular}{clcc}
\hline No & \multicolumn{1}{c}{ Description } & Frequency (\%) & Score \\
\hline $\mathbf{X}_{\mathbf{4 . 1}}$ & Training Ground & 22 & \\
& Strongly Agree & 52 & 110 \\
& Agree & 25 & 208 \\
& Neutral & 1 & 75 \\
& Disagree & 0 & 2 \\
& Strongly Disagree & 100 & 0 \\
\cline { 2 - 4 } & \multicolumn{1}{c}{ Total } & 395 \\
\hline $\mathbf{X}_{4.2}$ & Competition Ground & 12 & 60 \\
& Strongly Agree & 45 & 180 \\
& Agree & 38 & 114 \\
& Neutral & 5 & 10 \\
& Disagree & 0 & 0 \\
\cline { 2 - 4 } & Strongly Disagree & 100 & 364 \\
\cline { 2 - 4 } & Total & $\mathbf{1 0 0}$ & $\mathbf{3 . 7 9}$ \\
\hline \multicolumn{2}{r}{ Average score }
\end{tabular}

Sources: Research Result

Table 6 showed that in terms of sale promotion variable on the decision visits in Bhakti Alam is based on the calculation of the total question asked on 2 (two) elements that represent aspects of decision visits. Based on cumulative table of sale promotion variable in Bhakti Alam ecotourism with a total score of 3.79 , sale promotion can influence respondents to visit based on the analysis of attitude scale: agree.

\section{The Visiting Decision}

The representative location of Bhakti Alam could affect the respondent to visit the place based on the calculation of the total question asked on 5 (five) elements that represent aspects of environment (Table 7). Based on cumulative table of decision visits in Bhakti Alam ecotourism with a total score of 3.88 , decision to visit Bhakti 
Alam affected by environment on the analysis of attitude scale: agree.

Table 7. The Visiting Decision (Y)

\begin{tabular}{|c|c|c|c|}
\hline No. & Description & Frequency (\%) & Score \\
\hline \multirow[t]{7}{*}{$Y_{1}$} & $\begin{array}{l}\text { Representative } \\
\text { Location }\end{array}$ & & \\
\hline & Strongly Agree & 24 & 120 \\
\hline & Agree & 54 & 216 \\
\hline & Neutral & 20 & 60 \\
\hline & Disagree & 2 & 4 \\
\hline & Strongly Disagree & 0 & 0 \\
\hline & Total & 100 & 400 \\
\hline \multirow[t]{7}{*}{$Y_{2}$} & Access Road & & \\
\hline & Strongly Agree & 17 & 85 \\
\hline & Agree & 59 & 236 \\
\hline & Neutral & 19 & 57 \\
\hline & Disagree & 5 & 10 \\
\hline & Strongly Disagree & 0 & 0 \\
\hline & Total & 100 & 388 \\
\hline \multirow[t]{7}{*}{$Y_{3}$} & $\begin{array}{l}\text { Representative } \\
\text { Condition }\end{array}$ & & \\
\hline & Strongly Agree & 21 & 105 \\
\hline & Agree & 55 & 220 \\
\hline & Neutral & 22 & 66 \\
\hline & Disagree & 2 & 4 \\
\hline & Strongly Disagree & 0 & 0 \\
\hline & Total & 100 & 395 \\
\hline \multirow[t]{7}{*}{$Y_{4}$} & Product & & \\
\hline & Strongly Agree & 16 & 80 \\
\hline & Agree & 49 & 196 \\
\hline & Neutral & 31 & 93 \\
\hline & Disagree & 4 & 8 \\
\hline & Strongly Disagree & 0 & 0 \\
\hline & $\begin{aligned} \text { Total } \\
\end{aligned}$ & 100 & 377 \\
\hline \multirow[t]{8}{*}{$Y_{5}$} & Price & & \\
\hline & Strongly Agree & 17 & 85 \\
\hline & Agree & 52 & 208 \\
\hline & Neutral & 27 & 81 \\
\hline & Disagree & 4 & 8 \\
\hline & Strongly Disagree & 0 & 0 \\
\hline & Total & 100 & 382 \\
\hline & Average score & 100 & 3.88 \\
\hline
\end{tabular}

\section{CONCLUSION}

The decisions to be interested in visiting Bhakti Alam ecotourism are affected by the variable of sale promotion, and then followed by public relations, personal marketing, and advertising. Visiting decision is more determined by factor of representative location followed by a representative conditions, road access, pricing and products.

Based on the data and the result of the analysis, it can be summarized which factors affected the visitors' decision to visit Bhakti Alam ecotourism. Those factors are advertisement, public relations, personal marketing, sale promotion, as well as decision to visit, which all of them affected significantly and positively to visit interest. The result indicated that if those factors are implemented more maximize, then the visitors' interest to visit Bakhti Alam will increase, thus it can support the ecotourism sustainability.

\section{REFERENCES}

[1]. Buhalis, D. 2000. Marketing the competitive destination of the future. Tourism Management 21(1), 97-116.

[2]. Chrismardani, Y. 2012. Komunikasi pemasaran terpadu. Jurnal Neo-Bis 8(2), 176-189.

[3]. Aprilia, R. P. and Sayatman. 2014. Perancangan media promosi langsung. Jurnal Sains dan Seni POMITS 3(2), 2337-3520.

[4]. Wandasari. 2013. Perlakuan akuntansi atas pph. Jurnal EMBA, 1(3), 558-566.

[5]. Sanusi, A. 2003. Metodologi penelitian praktis: untuk ilmu sosial dan ekonomi. Buantara Media. Malang.

[6]. Santoso, P. B. 2005. Analisis statistik dengan microsoft excel dan spss. Andi Publisher. Yogyakarta.

[7]. Kusmayadi and E. Sugiarto. 2000. Metode penelitian dalam bidang kepariwisataan. PT Gramedia Pusataka Utama. Jakarta.

[8]. Areks, E., M. Nadjib and S. Cangara. 2015. Pengaruh penggunaan bauran promosi terhadap tingkat kunjung wisatawan. Jurnal Komunikasi Kareba, 4(4), 360-373.

[9]. Tjiptono, F. 2008. Strategi pemasaran. Andi Publisher. Yogyakarta.

[10]. Widayanti, R. 2012. Pengaruh bauran promosi terhadap kunjungan wisatawan domestik (Studi Kasus di Taman Rekreasi Sengkaling Malang). Jurnal Dinamika Dotcom 3(1), 1-17.

[11]. Kotler, P. and K. Keller. 2009. Manajemen pemasaran, $2^{\text {nd }}$ Ed. Erlangga. Jakarta.

[12]. Andreansyah, R. B. and Triyuniati. 2014. Pengaruh strategi promosi terhadap keputusan berkunjung wisatawan mancanegara. Jurnal Ilmu dan Riset Manajemen 3(6), 1-17.

[13]. Wardah, Z., Topowijono and M. G. Wi Endang NP. 2016. Pengaruh bauran promosi terhadap keputusan berkunjung (Survei pada Pengunjung Taman Safari II Prigen Pasuruan). Jurnal Administrasi Bisnis 40(1), 23-30. 